\title{
Religion - The Discipline of Restoring Communion Between People
}

\section{Ionel Ene}

Prof. “Dunărea de Jos” University - Galați, Romania

\begin{abstract}
We are tempted to make a hierarchy of disciplines, both in pre-university education, but sometimes even in university. Usually, the emphasis is on the disciplines in the real area, to the detriment of those in the human area. We go further and do the hierarchy in the same area and we have the feeling that physics is more important than mathematics, or chemistry is more valuable than technology and so on. As for the humanist side, philosophy and political science have long surpassed linguistics and history. In this context we ask ourselves: where is the place of theology or religion? To what extent can religion or theology contribute to the completion of the profile of the new man? As the importance of the spiritual component in the formation of young people is increasingly relativized and diminished, to the detriment of the somatic one, we wonder if religion was not misperceived and taught. This is why we would like to proclaim the truth about Christianity, which we should discover as clean and clear as spring water, in the discipline taught in schools.
\end{abstract}

Keywords: religion, Christianity, school, education

\section{Introduction}

Today's world could not move forward without education! Unfortunately, its forms of relativization are multiple. On the one hand, there is an obvious tendency to specialize, especially in the technical side, on the other hand the general knowledge, essential in the formation of any earthling, is increasingly reduced. There is a considerable gap between technical and humanistic research, highlighted by the very special forms of language. In fact, we must point out that with industrialization and technology, a specific language has been created, which is difficult to access for other scientific research faults. It would be enough to refer to the language and vocabulary specific to the field of informatics, which remains an enigma to the writer or plastic artist, but the reciprocal is equally valid. The divorce between the technical and the humanistic world can be captured at the dawn of the industrialization era, each field creating its own portfolio, difficult to access the other. The same is true between theology and science, because scientific research has developed independently of theology, after it has been reluctantly viewed and excluded from the humanities. 
Theology has preserved its language, but it is as inaccessible to modern man as IT language is foreign to the poet or painter. In fact, we must point out that the Church, in general, practiced the method of diastasis, of separation from culture and not of synthesis, as the scholastics did! This explains why theological language has gradually become less accessible to people of culture and beyond.

A particularly important moment in the Science - Religion relationship, at least in Romania, was the change of political regime in December 1989. Communist ideology, with the obligation to accept the materialist conception of the world, was abandoned and freedom of expression, choice and they made room in society. Weak at first, but statuary later, a new discipline appeared in the pre-university curriculum. That discipline was Religion. It was then a total investment of confidence in changing things for the better and a return to normalcy. Unfortunately, more than three decades later, we find that the investment is far from materialized! It's hard to be surprised in a communication why he got here. Anyway, then we hoped that the presence of the Religion class in School will shape the profile and character of the child according to the objective proposed by the discipline. Today, we find that young people are further away from the Christian way of life than those before "89. How was that possible?

First of all, after a half-century disappearance in the school curriculum, Religion returned to the educational landscape, without a clarification of the proposed objective and adaptation of the content to achieve it. In a hurry, in order to meet the requirement, curricula were embedded, textbooks were drawn up, following the interwar model, then a revision was made and certain disciplines from the seminar curriculum were adopted. At the beginning there were disciplines divided into training cycles, then several topics from each discipline were interspersed and this is how the textbooks were designed, existing even today. The first big issue was content. The authors did not ask the question of finality, so what did the students want to achieve by going through those textbooks ?! In fact, the contents were part of the seminar textbooks, which aimed to train the future servants of the holy altars, or the goal proposed by the discipline Religion, taught in pre-university education, could not be identical! The contents had to be adapted to another objective, because in preuniversity education the students were not preparing to become priests, but good Christians. Unfortunately, the contents of the discipline, even in its current form, are far from achieving this goal, because they are extremely dense in information and only the teacher's ability could make things right.

The second problem was related to teacher training. With two exceptions, Bucharest and Sibiu, the Faculties of Theology were established in different university centers and the students had to take psycho-pedagogical training courses with teachers who had the method of teaching, but did not know the theological contents. Only the pedagogical vocation could turn young graduates from information providers into artists and modelers of Christian characters! Thus, after three decades of teaching Religion in pre-university education, without generalizing, there are many young 
people who did not approach the Church, but on the contrary. And this is a natural consequence of the fact that the discipline of Religion did not reach its goal, but, through the dense contents in information and the lack of vocation of the teachers, it managed to cultivate the repulsion towards the Church! The fact that even in the School Religion was and still is viewed with restraint, and the specialized teacher sometimes feels awkward, not to mention that he lives in an inferiority complex contributed to the situation we live in today!

\section{The investigated problem}

In these conditions, it is natural to ask ourselves, how can Religion become, in this period of pandemic, a discipline of restoring communion between people?

The answer can be a simple one: by re-evaluating the discipline and the teacher who teaches it! But what is and what should be the discipline and who is and what should be the teacher?

To better understand what the discipline of Religion is, we should first define Christianity, which is viewed with restraint and misunderstood today. Why is it viewed with restraint? Because it is included in the sphere of Religion and, often, assimilated with other religions.

Christianity is, by excellence, a way of life. It is an invitation to a partnership of eternal love with God. The essence of Christianity is the Love of God Sacrificed in History. Whoever responds to the invitation that God makes, struggles all his life to live according to the model discovered by God in history in the person of His Son Jesus Christ. The invitation is addressed to all people, from all places and from all times! Once assumed, the invitation is translated into gestures, deeds, attitudes, confessions, etc., which spring from each respondent's desire to identify with Jesus Christ, hence the christian name - Christianos -Christ. We can capture here an extremely important nuance of the change of human destination through Jesus Christ. In our faith, mankind has its existence in the creative act and is the descendant of Adam! If Adamah means earth, from where humanity, man, then we realize that the destination of all who lived to Jesus Christ was the earth! If the name of the Christian, which came through the Latin line, ennobles the spirited huma, as Creangă said of him - man - then the destination of all who believe in Christ is heaven, because Christ came to earth to give us a new identity, even to make us brothers of His and sons of God. To be earthly, but to have the conviction that living a life of nobility, in humble love and beloved humility, you will become the heir of heaven is the greatest comfort to the soul of any mortal!

From the consciousness of the high calling, to which he is expected to answer, every Christian struggles to have his whole life shaped in the image of Christ and every thought, gesture, word, deed, attitude, confession, etc., etc., to spring from love and materialize as such! In this sense, the Christian's gestures become religious acts and permanently strengthen the communion of love with God and others at the same time! 
When the simplest gestures, which any Christian observes, do not spring from this consciousness and desire to reach the likeness of Jesus Christ, they become simple forms without substance! Ritual and forms of expression, unsprising from this desire and consciousness lead to unproductive ritualism and formalism. In this respect, the Christian cult must also be understood, either publicly or privately. ny religious service, whether public or private, springs from this consciousness and is the burning desire to update the entire work of redemption from the power of death and darkness, committed by Jesus Christ, objectively for all people of all times and all places. The Christian, knowing his limits, constantly begs Jesus Christ to perform the same work, once again with him, to subjectively himself, what He has done objectively for all! Participation in any divine public service is not participation in a show, but a constant desire to pretend from good to better, to the likeness of God, which is the essential objective of every Christian! In this sense, I have said that there is no more wonderful way of life on earth than that in which you want to become god yourself, but a god with and in God, not a God without God, as things often happen today. Everything that is happening in the world today is clear proof that man wants to be God, and by this he answers his vocation, the calling that God has made to us since the Face. Unfortunately, it is a desire that disregards the divine Revelation, which was perfected in Jesus Christ and which became the model and source of human deity. Today's man repeats the mistake of Adam, who wanted to be like God, but without God, as Lucifer once did!

The Religion Discipline must transfer this truth to the cognitive and affective reality of each student. The main objective of the discipline is to permanently proclaim Christianity as the most wonderful way of life and to help the student shape himself in the image of Christ, Our Lady, and the Saints. To be able to love all people and all creation, to be sure that you love God, or not to hate anyone so that you do not hate God is the most wonderful way of peace, peace, hope and fulfillment of this world. To achieve this goal religion discipline must adapt its contents, which are scholastic, for the most part. A total fulfillment of the current contents would give the student some ability to define Christianity, but not to live it! The objective of the discipline is to help the students live Christianity, even if they were not masters in defining it! Changing content is not an easy job, because it would be necessary to combine the experience of all teachers of religion, vocation, a redefinition of the objective and function of the objective elaborated the contents. Current manuals betray a copy of content from seminar manuals and a nebula in terms of what the goal to achieve means.

If this meant re-evaluating the discipline, we also need to see what it means to reevaluate the teacher, as mentioned above! By not understanding Christianity as a way of life and having preconceived ideas or being influenced by the funny Bible, certain people have had and still have reservations about the presence of Religion, among the disciplines of the pre-university curriculum. It is their right to make their point, but far too far and too bold to impose it on all. All the more so since we must constantly proclaim Christianity as an invitation to assume a way of life. No one is obliged to 
answer, but no one is excluded from the invitation. What right do some people have to answer for others? Either it is freedom and then everyone can say yes or no to God, or it is the dictatorship of the minority and then some may decide on behalf of all! We must admit, however, that certain grievances in the way religion classes have been conducted, in all these years of freedom, have thrown out certain question marks, doubt marks or even created discontent, both among students and parents. Well, some of the students who were unhappy yesterday with the way Religion was taught, touched by the anti-clerical and anti-clerical drink supported by certain neo-Marxist currents, are totally against teaching this discipline in pre-university education. The fact that the religion teacher was sometimes content with the mere transmission of religious information, without a assiduous concern in the formation of future Christians, who are also the best citizens of the homeland but also the closest sons of God, has led to the situation today. As man finds it difficult to distinguish between sin and sinner, it has been easier for him to hate both sin and sinner. In other words, seeing that a teacher is not doing his job properly at the School, he did not fight to correct or change him, but decided to tear down the School. In this respect, some students, dissatisfied with the way the religion teacher transmitted to them a large amount of information, without pursuing their transfer to the affective-behavioral side, cultivated aversion against discipline and not sympathy for the teacher's lack of vocation. What does it mean to re-evaluate the religion teacher? Nothing but better management of framework policy, a verification of the teaching vocation and adequate specialist training. Specialized training, i.e. a good knowledge of content, psycho-pedagogical training, i.e. the ability to transmit information, as well as the teaching vocation, will contribute to the achievement of the essential objective of Religion as an educational discipline in the pre-university curriculum.

\section{Research, Study Proposals - Divine Pedagogy}

It would be particularly important, in our desire to train young people for the future, to use divine pedagogy. What does divine pedagogy actually mean?

The extremely sensitive manner of man's address, used by God, the way he respects his freedom and discovers his truth, and not only, is part of divine pedagogy. For example, the dialogue between God and Adam after the fall into sin is masterful in this sense. Reality is rendered by Moses, in the book of The Making, in chapter III, verses 9-19, but the beginning reveals divine pedagogy: "And the Lord God called Adam, and said to him: Adame, where are you? Answer this: I heard your voice in heaven and I feared, for I am naked and I hid. And God said, "Who told you you were naked?" Didn't you just eat from the tree I ordered you not to eat from? Said Adam: The woman you gave me to be with me, that gave me the tree and I ate" and the dialogue continues. It is important to make some clarifications about this dialogue. First of all, God behaves with such delicacy and disregards Adam's lack of gratitude. He knew that Adam had breaking the commandment, but he did not offend him, despise him, not accuse him, but he would bring him into the position of being easy for him to recognize, to say a 
simple YES, without further explanation. The interrogative form used by God made Adam's answer easier: Didn't you eat from the tree, from which I commanded you not to eat? For Adam it was very simple to answer: Yes, Lord, I was wrong, please forgive me! But he not only did not give a simple and short answer, taking responsibility for the deed, but he accused God: The woman you gave me to be with me, that gave me the tree and I ate, in other words: You are guilty of giving me the woman! How much delicacy to God and how disrespectful and grateful to man! Another thing worth remembering is that God did not come to Adam as soon as he was wrong, but let the day pass, and He came to the cool of the evening (Genesis III, 8), that is, gave Adam time to realize the mistake. Besides, God is waiting for us to receive his love, for that means responding to his invitation to the last breath of earthly life. Man, by the way, did not understand at the dawn of creation how much the Creator loves him! He did not understand that God had called him to come as he did on the path of knowledge and experience, a reality expressed by the commandment given to the making: Grow and multiply and fill the earth and master it. (Genesis I, 28). The word increase meant increase in the discovery and knowledge of the reasons of all creatures, which would have given them the ability to understand their own limited existence, in relation to God, the existence of all existences! Tempted by the serpent, through a woman, Adam wanted to overcome this effort, to decipher the rationality of creatures and to acquire knowledge, biting from the tree of knowledge and thus breaking God's will, breaking the communion of love with Him! This is, moreover, ancestral sin, for the tree of the knowledge of good and evil was not distinct from the others, but it expressed the limit of human knowledge. In this sense, Antony Flew's testimony is significant, that the rationality of the world postulates a reason above it and that a DNA beam, through the almost impossible complexity of the arrangements necessary to produce life, implies a superior external intelligence ${ }^{1}$. Perhaps much clearer, in this regard is Father Dumitru Staniloae, who confessed, among other things, in his treatise on Dogmatics: "The Logos or Word of God has been in the world since its inception on the one hand by the reasons of things, which are faces created and sustained by His eternal reasons, on the other hand, by human persons, who in their living rationality are the faces of His own hypostasis, created for the purpose of thinking the reasons of things together with the personal divine Reason in a dialogue with Her"2. Adam was called to discover the rationality of all creatures and thereby realize that a Reason, above all reasons discovered in creatures, must have arranged everything. Unfortunately, it took thousands of years for man to discover this truth, proclaimed by the Son of God, Jesus Christ, although there are still enough people today who, in the name of reason, base the appearance of life on chance, to the detriment of rationality. the world. In reality, what is chance, than what a French thinker once rightly stated: "the word with which we cover our ignorance and which, apart from

\footnotetext{
${ }^{1}$ See, in this sense Antony FLEW, Roy VARGHESE, There is a God - how the word $\sim \mathrm{s}$ most notorious atheist changed his mind, ed. Haper -Collins, New York, 2007.

2 Rev. Prof. Dr. Dumitru STĂNILOAE, Orthodox Dogmatic Theology for Theological Institutes, vol. II, ed. BOR Biblical and Mission Institute, Bucharest, 1978, p. 7.
} 
explaining things, implies giving up any attempt at explanation, even the abdication of thinking itself" 1 .

Divine pedagogy invites us to research the existential data and to understand that every creature in the universe bears the imprint of the Creator, from the DNA bundle, stated by Flw to the harmony of the Universe, which postulates the existence of the Creator, according to Voltaire: The universe confuses me and not I can at least think that there is a clock, without a clock! The reluctance of some, in general towards Christianity and especially towards the discipline of Religion, is nothing but proof of an ignorance of the substance of the problem. In fact, atheism is, as Flew himself pointed out, the result of a deliberate refusal to look at the evidence that is available in our immediate experience"2. But divine pedagogy invites us to respect every creature, according to the measure of its rationality and even more so the most wonderful of creatures, which is the human person. If God was so sensitive to an Adam who fell out of fellowship with Him, how much more must we be with one another. This is the role of the discipline of Religion at this time: to rediscover the value of the human being, to constantly proclaim the primacy of love, and to stop the competition of hatred, pride, primacy of jurisdiction, primacy of any kind. The essential objective of this discipline is to discover to the child his value, but also the value of his colleagues and to develop skills of communion in love, of assuming responsibility and discovering the plasticized reasons, present in any creature, towards a correct use of their. This requires a lot of consistency, insistence, motivation and patience. The ecumenical patriarch, Bartholomew I, when asked why young people today are so unhappy, replied: because they do not have the patience to know each other ${ }^{3}$.

The purpose of our endeavor is to convince ourselves, if necessary, that we are invited to rediscover Christianity, as the most wonderful way of life, as the greatest dignity that man can access on earth: it is an invitation to a love partnership with God, what sums up, as many partnerships with as many people we meet on the paths of this life. If every person understood any manifestation as springing from this consciousness, then it would no longer be a dispute between rites, forms of manifestation, partisan conceptions, desires for supremacy, etc., etc., but it would be a competition in goodness, in which the standard to be achieved is Deification, and the competition would be with ourselves.

The discipline of Religion would give us the first ways to access this redoubt to be conquered! But it would create abilities that could be used throughout life, for the rebirth of a better, more humble world, closer to the natural human and Christian, at the same time.

\footnotetext{
${ }^{1}$ A Ioan Gh. SAVIN, Apologetica, ed. Anastasia, Bucharest, 2003, vol.II, p. 132.

2 Antony FLEW, Roy VARGHESE, There is a God, pp. 163.

3 Olivier CLEMENT, Ecumenical Patriarch Bartholomew I, translated by Mihai Maci, from lb. French. The truth will set you free: Interviews with Ecumenical Patriarch Bartholomee I. Editions Jean Claude Lattes, Desclee de Brouwer, 1996, and in Romanian in Deisis Publishing House, Sibiu, 1997, p. 111.
} 


\section{Conclusions}

A discipline cannot change a world, but the world can accept a discipline! If this discipline will not present the content like any of its catalog sisters, but will set a clear goal and use appropriate methods to achieve it, then Religion will be the discipline that will restore communion between people, a communion weakened by the current pandemic. The effort must be supported by the Institution - the School, but also by its servant - the vocation teacher.

\section{References}

[1] A Ioan Gh. SAVIN, Apologetica, ed. Anastasia, Bucharest, 2003, vol.II, p. 132.

[2] Abou-Rahme, Dr. Farid, Si Dumnezeu a Zis... Autoritatea Bibliei Confirmata De Stiinta, Ed. Logos, Cluj-Napoca, 1998.

[3] Antony FLEW, Roy VARGHESE, There is a God - how the word s most notorious atheist changed his mind, ed. Haper -Collins, New York, 2007.

[4] Antony FLEW, Roy VARGHESE, There is a God, pp. 163.

[5] Biblia, Sau Sfânta Scriptură, Ed. Sf. Sinod Al Bor, București, 1968.

[6] Bute, Ioan, Are Evoluționismul Dovezi Științifice?, Ed. Corgal Press, Bacău, 2014.

[7] Clement, Olivier, Patriarhul Ecumenic Bartolomeu I, Trad De Mihai Maci, Din Lb. Franceză. La Verite Vous Rendra Libre: Entretiens Avec Le Patriarche Oecumenique Bartholomee I-Er. Editions Jean Claude Lattes, Desclee De Brouwer, 1996, Iar În Româneşte În Editura Deisis, Sibiu , 1997.

[8] Eliade, Mircea, Istoria Credinţelor Şi Ideilor Religioase, Volumul I: De La Epoca De Piatră La Misterele Din Eleusis, Ed. Știnţifică Şi Enciclopedică, București, 1981.

[9] Ene, Petru Viorel, Profesorul Ioan Gh. Savin. Viața, Opera Și Actualitatea Principiilor Sale Apologetice, (Teză De Doctorat), Ed. Vasiliana"98, Iași, 2019.

[10] Flew, Antony, Roy Varghese, There is a God - How the Word S Most Notorious Atheist Changed His Mind, Ed. Haper -Collins, New York, 2007.

[11] Lemeni, Adrian, Ionescu, Pr.Răzvan, Mihalache, Diac. Sorin, Ioja,Cristinel, Apologetica Ortodoxă, Vol. I, Ed. Basilica, București, 2013.

[12] Olivier CLEMENT, Ecumenical Patriarch Bartholomew I, translated by Mihai Maci, from lb. French. The truth will set you free: Interviews with Ecumenical Patriarch Bartholomee I. Editions Jean Claude Lattes, Desclee de Brouwer, 1996, and in Romanian in Deisis Publishing House, Sibiu, 1997, p. 111.

[13] Rev. Prof. Dr. Dumitru STĂNILOAE, Orthodox Dogmatic Theology for Theological Institutes, vol. II, ed. BOR Biblical and Mission Institute, Bucharest, 1978, p. 7. 
[14] Rose, Ieromonah Serafim, Cartea Facerii, Crearea Lumii Şi Omul Începuturilor - Perspectiva Creştin - Ortodoxă, Trad. De Constantin Făgețean, Ed. Sofia, București, 2001

[15] Savin, Ioan Gh., Apologetica, Ed. Anastasia, București, 2003, Vol. Ii.

[16] Stăniloae, Pr. Prof. Dr. Dumitru, Teologie Dogmatică Ortodoxă Pentru Institutele Teologice, Vol. Ii, Ed. Institutului Biblic Și De Misiune Al Bor, București, 1978.

[17] Udriște, Dr. Octavian, Cum a Creat Dumnezeu Universul Din Nimic, Ed. Tabor, Rm. Vâlcea, 1994. 